\section{KONSEP MANAJEMEN KESISWAAN}

Nurmadiah, M.A.

Dosen Fakultas Ilmu Agama Islam Universitas Islam Indragiri (FIAI - UNISI) Tembilahan

\section{Abstrak}

Siswa merupakan aset umat dan bangsa, secara prinsipil pembinaannya ditaklifkan pada kedua orang tua, karena sesuatu dan lain hal maka wewenang itu dilimpahkan kepada para pendidik. Lembaga pendidikan (top manager) sebagai pelaku dan pengemban amanah Allah dan umat dituntut memberikan proses terbaik hingga mengeluarkan (out put) yang dapat memenuhi kebutuhan tripusat pendidikan. Sekolah memegang peranan penting dalam mengelola sekolah. Ia bertanggung jawab sepenuhnya terhadap berlangsungnya proses pembelajaran di suatu sekolah. Seorang kepala sekolah dituntut mampu memberiakan ide-ide cemerlang, memprakarsai pemikiran yang baru di lingkungan sekolah dengan melakukan perubahan maupun penyesuaian tujuan, sasaran dari suatu program pembelajaran. Sebagai pemimpin seorang kepala sekolah dituntut dapat menjadi seorang inovator. Oleh sebab itu, kualitas kepemimpinan kepala sekolah sangat signifikan sebagai kunci keberhasilan bagi proses pembelajaran yang berlangsung disuatu sekolah. Ada beberapa elemen penyeleng garaan pendidikan yang harus selalu dibina oleh kepala sekolah yang dikemukakan oleh Wahjosumidjo yang terangkum dalam bukunya Kepemimpinan Kepala Sekolah; Tinjauan Teoritik dan Praktik yang meliputi program pengajaran, sumber daya manusia, sumber daya yang bersifat fisik dan hubungan kerja sama antara sekolah dengan masyarakat. Inilah elemen penyelenggaraan pendidikan yang harus selalu mendapatkan perhatian dari kepala sekolah demi tercapainya tujuan suatu lembaga pendidikan.

Kata kunci: Manajemen dan siswa

\section{A. Pendahuluan}

Keberhasilan dalam penyelenggaraan lembaga pendidikan (sekolah) akan sangat bergantung kepada manajemen komponen komponen pendukung pelaksanaan kegiatan seperti kurikulum, peserta didik, pembiayaan, tenaga pelaksana, dan sarana prasarana. Komponen-komponen tersebut merupakan satu kesatuan dalam upaya pencapaian tujuan lembaga pendidikan (sekolah), artinya bahwa satu komponen tidak lebih penting dari komponen lainnya. Akan tetapi satu komponen memberikan dukungan bagi komponen lainnya sehingga memberikan kontribusi yang tinggi terhadap pencapaian tujuan lembaga pendidikan (sekolah) tersebut.

Komponen peserta didik keberadaannya sangat dibutuhkan, terlebih bahwa pelaksanaan kegiatan pendidikan di sekolah, peserta didik merupakan subyek sekaligus objek dalam proses transformasi ilmu pengetahuan dan ketrampilan yang diperlukan. Oleh karena itu keberadaan peserta didik tidak hanya sekedar memenuhi kebutuhan saja, akan tetapi harus menjadi bagian dari kebermutuan dari lembaga pendidikan (sekolah). Artinya bahwa dibutuhkan Manajemen peserta didik yang bermutu bagi lembaga pendidikan (sekolah) itu sendiri. Sehingga peserta didik itu dapat tumbuh dan berkembang sesuai dengan potensi fisik, kecerdasan intelektual, sosialemosional, dan kejiwaan peserta didik.

Kebutuhan peserta didik dalam mengembangkan dirinya tentu saja beragam dalam hal pemrioritasan, seperti para peserta didik ingin sukses dalam hal prestasi akademiknya, disisi lain ia juga ingin sukses dalam hal sosialisasi dengan teman sebayanya. Bahkan ada juga peserta didik yang ingin sukses dalam segala hal. Pilihan-pilihan yang tepat atas keberagaman keinginan tersebut tidak jarang menimbulkan masalah bagi para peserta didik. Oleh karena itu diperlukan layanan bagi peserta didik yang dikelola dengan baik. Manajemen peserta didik berupaya mengisi kebutuhan akan layanan yang baik tersebut, mulai dari peserta didik tersebut mendaftarkan sekolah sampai peserta didik tersebut menyelesaikan studi di sekolah tersebut.

\section{B. Pengertian, Prinsip dan Fungsi-Fungsi Manajemen}

1. Pengertian

Manajemen secara etimologi berasal dari Bahasa Inggris, yaitu dari kata kerja to manage artinya mengurus, mengatur, menggerakkan dan mengelola. ${ }^{1}$ Dengan demikian manajemen secara bahasa adalah pengurusan, pengaturan, penggerakan, dan pengelolaan.

Secara terminologi manajemen sering disandingkan dengan

1 John M. Echol dan Hasan Shadily, Kamus Inggris Indonesia, (Jakarta : PT Gramedia, 1996),cet. XXIII, hal. 372 
administrasi, sehingga muncul tiga pandangan berbeda:1) memandang administrasi lebih luas dari pada manajemen; 2) mengartikan manajemen lebih luas dari pada administrasi; 3) menganggap manajemen sama dengan administrasi. ${ }^{2}$ Dalam penulisan selanjutnya istilah manajemen sama dengan administrasi, karena keduanya mempunyai fungsi yang sama.

Menurut Terry sebagaimana dikutip Ngalim Purwanto management is a district proses consisting of planning, organizing, actuatingand controlling performed to determine and accomplish stated objectives bythe use of human being and other resources. ${ }^{3}$ Manajemen adalah proses tertentu yang terdiri dari perencanaan, pengorganisasian, pergerakan dan pengawasan yang dilakukan untuk menentukan dan mencapai tujuan yang ditetapkan dengan menggunakan sumber daya personal maupun material.

Diantara pengertian manajemen secara terminologi adalah seperti yang diungkapkan Peter P. Schoderbek management is a procces ofachieving organizational goals through other. ${ }^{4}$ Manajemen adalah proses pencapaian tujuan organisasi melalui orang lain.

Menurut Ibrahim Ishmat Muthowi manajemen adalah :

إنّ ادارة هى الإصطلاحة الذى يطلق على التوجيه والرقابة و دفع القوى العاملة

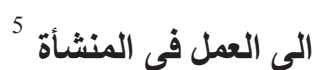

Artinya: Sesungguhnya manajemen adalah suatu aktivitas yang melibatkan proses pengarahan, pengawasan dan pengerahan segenap kemampuan untuk melakukan suatu aktivitas dalam suatu organisasi.

Sehingga manajemen dapat diartikan suatu proses sosial yang direncanakan untuk menjamin kerja sama, partisipasi dan keterlibatan sejumlah orang dalam mencapai sasaran dan tujuan terten-

2 E. Mulyasa, Manajemen Berbasis Sekolah, (Bandung: PT. Remaja Rosda Karya, 2003), cet.III dan IV, hal. 19

3 Ngalim Purwanto, Administrasi dan Supervisi Pendidikan, (Bandung: PT. Remaja Rosda Karya, 1995), cet. VII, hal. 7

4 Peter P. Schoderbek, et.al., Management, (Florida: Harcourt Brace Jovanovich Inc., 1988), hal..8

5 Ibrahim Ishmat Mutthowi, Al-Ushul Al-Idariyah li al-Tarbiyah, (Riyad: Dar al-Syuruq, 1996), hal. 13. tu yang ditetapkan secara efektif. Manajemen mengandung unsur bimbingan, pengarahan, dan pengerahan sekelompok orang terhadap pencapaian sasaran umum. Sebagai proses sosial, manajemen meletakkan fungsinya pada interaksi orang-orang, baik yang berada di bawah maupun berada di atas posisi operasional seseorang dalam suatu organisasi. ${ }^{6}$

Hal ini menunjukkan bahwa salah satu fungsi manajemen adalah menempatkan orang pada posisinya yang tepat. Rasulullah Saw memberi contoh dalam hal ini sebagaimana menempatkan orang di tempatnya. Hal ini misalnya dapat dilihat bagaimana Abu Hurairah ditempatkan oleh Rasulullah Saw sebagai penulis hadis atau dapat dilihat bagaimana Rasulullah menempatkan orang-orang yang kuat setiap pekerjaan dan tugas sehingga posisinya benar-benar sesuai dengan keahliannya.

Dari pemikiran-pemikiran di atas dapat dipahami unsur-unsur yang terkandung dalam manajemen adalah:

a. Bahwa manajemen diperlukan untuk mencapai tujuan dan pelaksanaan.

b. Manajemen merupakan sistem kerja sama yang kooperatif dan rational.

c. Manajemen menekankan perlunya prinsip-prinsip efisiensi.

d. Manajemen tidak dapat terlepas dari kepemimpinan atau pembimbing.

\section{Prinsip Manajemen}

Pentingnya prinsip-prinsip dasar dalam praktik manajemen antara lain menentukan metode kerja, pemilihan pekerjaan dan pengembangan keahlian, pemilihan prosedur kerja, menentukan batas-batas tugas, mempersiapkan dan membuat spesifikasi tugas, melakukan pendidikan dan latihan, melakukan sistem dan besarnya imbalan itu dimaksudkan untuk meningkatkan efektivitas, efisiensi, dan produktivitas kerja. ${ }^{?}$

\footnotetext{
6 Soegabio Admodiwiro, Manajemen Pendidikan Indonesia, (Jakarta: PT Arda Dizya Jaya,2000), hal. 5

7 Nanang Fattah, Landasan Manajemen Pendidikan, (Bandung: PT Remaja Rosda-
} karya, 2000), hal. 12 
Dalam kaitannya dengan prinsip dasar manajemen, Fayol mengemukakan sejumlah prinsip manajemen, yaitu :

a. Pembagian kerja

Semakin seseorang menjadi spesialis, maka pekerjaannya juga semakin efisien.

b. Otoritas

Manajer harus memberi perintah/tugas supaya orang lain dapat bekerja.

c. Disiplin

Setiap anggota organisasi harus menghormati peraturan-peraturan dalam organisasi.

d. Kesatuan perintah

Setiap anggota harus menerima perintah dari satu orang saja, agar tidak terjadi konflik perintah dan kekaburan otoritas.

e. Kesatuan arah

Pengarahan pencapaian organisasi harus diberikan oleh satu orang berdasarkan satu rencana.

f. Pengutamaan kepentingan umum/organisasi dari pada kepentingan pribadi.

g. Pemberian kontrak prestasi

h. Sentralisasi/pemusatan

Manajer adalah penanggung jawab terakhir dari keputusan yang diambil.

i. Hierarki

Otoritas wewenang dalam organisasi bergerak dari atas ke bawah.

j. Teratur

Material dan manusia harus diletakkan pada waktu dan tempat yang serasi.

k. Keadilan

Manajer harus adil dan akrab dengan bawahannya.

1. Kestabilan staf

Perputaran karyawan yang terlalu tinggi menunjukkan tidak efisiennya fungsi organisasi.

m. Inisiatif

Anggota harus diberi kebebasan untuk membuat dan menjalankan rencana.

n. Semangat kelompok
Peningkatan semangat kelompok akan menimbulkan rasa kesatuan. $^{8}$

\section{Fungsi-Fungsi Manajemen}

Menurut Siagaan dalam Soebagio, fungsi manajemen adalah tugas-tugas tertentu yang harus dilaksanakan sendiri. ${ }^{9}$ Para ahli manajemen mempunyai pendapat yang beraneka ragam tentang fungsi manajemen, yang paling awal adalah pendapat Fayol yaitu: planning, organizing, commanding, coordinating, dan controlling. Gulich membagi fungsi manajemen menjadi 7 yang dikenal dengan POSDCOR (planning, organizing, staffing, directing,controlling, reporting dan budgeting). Sedangkan Terry menyatakan 4 fungsi manajemen POAC (planning, organizing, actuating dan controlling). ${ }^{10}$ Pendapat di atas adalah sebagian dan sekian banyak pendapat yang dikemukakan oleh para ahli. Dari beberapa pendapat yang dikemukakan terdapat perbedaan secara komposisi dan terminologinya, namun pada intinya mempunyai kesamaan. ${ }^{11}$

Beberapa kesamaan tersebut, dan pada umumnya digunakan pada lembaga-lembaga pemerintahan di Indonesia adalah perencanaan, pengorganisasian, penggerakan, dan pengawasan.

\section{a. Perencanaan (Planning)}

Perencanaan merupakan penentuan kegiatan yang akan dilaksanakan pada masa depan. Aktivitas ini dilakukan untuk menentukan tindakan agar mencapai hasil yang diinginkan. Perencanaan dalam bahasa Arab disebut niat, yaitu formulasi tindakan di masa mendatang yang diarahkan kepada tujuan yang akan dicapai oleh organisasi. ${ }^{12}$

8 Kadarmansi dan Jusuf Udaya, Pengantar Ilmu Manajemen, (Jakarta: PT Gramedia Pustaka Utama, 1992), hal. 32

9 Soebagio Atmodiwirio, Manajemen Pendidikan di Indonesia, (Jakarta: Ardadizya Jaya, 2000), hal. 13

10 Manullang, Dasar-Dasar Manajemen, (Jakarta: Ghalia Indonesia, 1983), cet. X, hal. 19

11 Nanang Fattah, Landasan Manajemen Pendidikan, (Bandung: Remaja Rosda Karya,2000),cet. III, hal. 13

12 Nanih Machendrawaty, Agus Ahmad Safei, Pengembangan Masyarakat Islam dari 
Jadi jika niatnya sekeras baja, hasil capaiannya pun akan setingkat itu. Kalau niatnya setinggi gagasan, kita akan menghasilkan sebesar dan sehebat itu. Dengan demkian, niat merupakan padanan planning dalam manajemen yang lebih bersifat intrinsik dan manusiawi.

Menurut P. Siagian dalam Marasudin, perencanaan adalah kemampuan untuk mengambil keputusan pada waktu sekarang tentang hal-hal yang akan dikerjakan di masa yang akan datang. ${ }^{13}$ Perencanaan bisa diumpamakan jembatan penghubung antara keadaan sekarang dengan keadaan yang diharapkan terjadi pada masa yang akan datang. Sedangkan menurut Sagala perencanaan adalah proses pemanfaatan sumber daya secara terpadu yang diharapkan dapat menunjang kegiatan-kegiatan dan upayaupaya yang akan dilaksanakan secara efisien dan efektif dalam mencapai tujuan. ${ }^{14}$

Uraian di atas perencanaan terkait dengan 3 hal yang harus ditetapkan, yaitu: 1) tujuan; 2) kegiatan; 3) sumber daya. Sebagaimanayang diungkapkan Nanang Fattah bahwa dalam perencanaan selalu terdapat 3 kegiatan, yaitu: 1) perumusan tujuan yang ingin dicapai; 2) pemilihan program untuk mencapai tujuan; 3) identifikasi dan pengerahan sumber daya yang selalu terbatas. ${ }^{15}$

b. Pengorganisasian (Organizing)

Setelah perencanaan dilakukan secara matang, maka tindakan selanjutnya adalah pengorganisasian, kegiatan ini menjembatani antara kegiatan perencanaan dengan kegiatan penggerakan. Perencanaan hanya sebatas kerangka kegiatan tanpa adanya subyek dan wewenang yang jelas maka tujuan kegiatan tidak akan tercapai sesuai dengan yang diharapkan. Pengorgan-

Ideologi, Strategi sampai Tradisi, (Bandung: PT Remaja Rosdakarya, 2001), hal. 137

13 Marasudin Siregar, "Pengelolaan Pengajaran; suatu Dinamika Profesi Keguruan", dalam Chabib Thoha (eds), PBM-PAI di Sekolah; Eksistensi Proses Belajar Mengajar Pendidikan Agama Islam, (Yogyakarta: Pustaka Pelajar, 1998), cet. I, hal. 187

14 Syaiful Sagala, Konsep dan Makna Pembelajaran untuk Membantu Memecahkan Problematika Belajar dan Mengajar, (Bandung: CV. Alfabet, 2004), hal. 141

15 Nanang Fattah, op.cit., hal. 49 isasian pada dasarnya pembagian tugas dan wewenangpersonil sesuai perencanaan yang telah ditetapkan. Firman Allah SWT. Surat Yasin ayat $38-40$ :

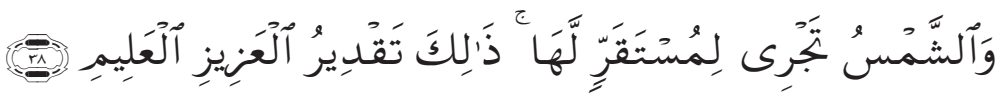

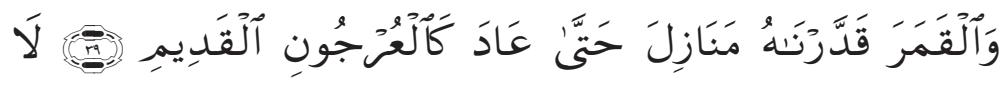

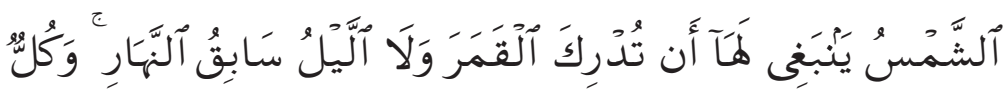

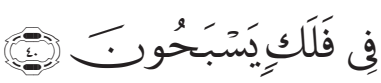

Artinya: "Dan matahari berjalan di tempat peredarannya. Demikianlahketetapan Yang Maha Perkasa lagi Maha Mengetahui. Dan telah Kamitetapkan bagi bulan manzilah-manzilah, sehingga (setelah dia sampai kemanzilah yang terakhir) kembalilah dia sebagai bentuk tandan yang tua.Tidaklah mungkin bagi matahari mendapatkan bulan dan malampun tidakdapat mendahului siang. Dan masing-masing beredar pada garis edarnya."

Menurut Sagala pengorganisasian adalah keseluruhan prose suntuk memilih orang-orang serta mengalokasikan sarana dan prasarana untuk menunjang tugas orang-orang itu dalam organisasi. ${ }^{16}$ Pembagian tugas dalam organisasi hendaknya dilakukan secara proporsional, yaitu membagi habis dan menstrukturkan tugas-tugas ke dalam sub-sub atau komponen-komponen organisasi.

Adapun menurut Ahmad Rohani dan Abu Ahmadi pengorganisasian adalah kegiatan administratif untuk menyusun struktur dan membentuk hubungan-hubungan kerja serta menentukan orang-orang yang diberi wewenang supaya diperoleh suatu keharmonisan usaha untuk mencapai tujuan bersama. ${ }^{17}$ Bentuk penyusunan struktur dan pembagian kerja yang dilaksanakan selalu terpancang pada tujuan yang ingin dicapai. Dari uraian di atas, dapat disimpulkan bahwa fungsi pengorganisa-

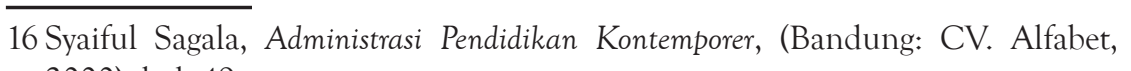
2000), hal. 49

17 Ahmad Rohani dan Abu Ahmadi, Pedoman Penyelenggaraan Administrasi Pendidikan Sekolah, (Jakarta: Bumi Aksara, 1991), cet.I, hal. 16 
sian mencakup 2 aspek (proses), yaitu :

a. Pembagian kerja dan pembagian beban kerja kepada individu atau kelompok

b. Penentuan garis-garis komunikasi, kekuasaan dan wewenang. ${ }^{18}$

c. Penggerakan (Actuiting)

Penggerakan merupakan aktualisasi dari perencanaan dan pengorganisasian secara konkrit. Perencanaan dan pengorganisasian tidak akan mencapai tujuan yang ditetapkan tanpa adanya aktualisasi dalam bentuk kegiatan. Perencanaan bagaikan garis start dan penggerakan adalah bergeraknya mobil menuju tujuan yang diinginkan berupa garis finish, garis finish tidak akan dicapai tanpa adanya gerak mobil.

Penggerakan menurut Terry dalam Sagala adalah perangsangan anggota-anggota kelompok agar melaksanakan tugas-tugas dengan antusias dan dengan kemampuan yang baik. ${ }^{19} \mathrm{Tu}$ gas penggerakan dilakukan oleh pemimpin, menurut Nanang Fattah pemimpin pada dasarnya seorang yang mempunyai kemampuan untuk mempengaruhi perilaku orang lain didalam kerjanya dengan menggunakan kekuasaan. Kemampuan umum untuk menggerakkan atau menggairahkan orang agar bertindak dinamakan motivasi. ${ }^{20}$

Menurut Tierauf dalam Sugandha motivasi adalah those innerdrives that activate or move an individual to action (dorongan dari dalam yang mengaktifkan atau menggerakkan seseorang untuk bertindak). ${ }^{21}$ Jadi, kepala sekolah sebagai seorang pemimpin instruksional, bertugas memberi motivasi bekerja kepada guru dan pegawai sekolah agar bersedia dan senang melakukan segala

18 Iwa Sukiswa, Dasar-Dasar Umum Manajemen Pendidikan, (Bandung: Tarsito, 1986) hal.30

19 Syaiful Sagala, Administrasi ..., op.cit., hal. 52

20 John Adair, Effective Leadership; A Self-Development Manual, Penerjemah Andre Asparyasogi, Menjadi Pemimpin Efektif, (Jakarta: PT Gramedia, 1994), cet. IV, hal. 177

21 Dann Suganha, Kepemimpinan di Dalam Administrasi, (Bandung: Sinar Baru, 1986), hal. 41 aktivitas dengan sendirinya dalam rangkap pencapaian tujuan pembelajaran secara efektif dan efisien. ${ }^{22}$

d. Kontrol/Evaluasi (Controlling)

Pengawasan merupakan pengontrol kegiatan yang telah dilaksanakan, apakah sesuai dengan tujuan yang telah ditetapkan atau tidak. Hal ini sesuai dengan firman Allah SWT.

\section{ما يلفظ من قول إلا لايها رقيب عتيد}

Artinya: Tiada suatu ucapanpun yang diucapkannya melainkan ada di dekatnya malaikat pengawas yang selalu hadir. ${ }^{23}$

Pengawasan diterapkan dalam fungsi manajemen, agar pelaksanaan kegiatan yang telah ditetapkan tidak melenceng dari perencanaannya, kalaupun ada penyimpangan-penyimpangan maka dilakukan perbaikan. Menurut Sagala pengawasan adalah kegiatan untuk mengetahui realisasi pelaku personel dalam organisasi, dan apakah tingkat pencapaian tujuan sesuai dengan yang dikehendaki, serta hasil pengawasan tersebut apakah dilakukan perbaikan. ${ }^{24}$ Dalam kegiatan ini juga dilaporkan faktor-faktor pendukung dan penghambat kerja, sehingga memudahkan usaha perbaikan. Jadi, pengawasan ini dilihat dari segi input, proses, output bahkan outcome-nya telah sesuai dengan tujuan yang ditetapkan atau belum sesuai dengan tujuan yang ditetapkan.

Menurut Nanang Fattah pengawasan dilakukan melalui 3 tahap; a) menetapkan standar pelaksanaan b) pengukuran pelaksanaan dibandingkan dengan standar, dan c) menentukan kesenjangan antara pelaksanaan dengan standar dan rencana. ${ }^{25}$ Tapi di dalamnya belum terdapat tahapan terakhir pengawasan yaitu upaya perbaikan. Dengan demikian, dapat disimpulkan bahwa pengawasan dilaksanakan melalui 4 tahap, yaitu :

1) Menetapkan standar-standar pelaksanaan pekerjaan sebagai

22 J. Riberu, Dasar-Dasar Kepemimpinan, (Jakarta: Pedoman Ilmu Jaya, 1992), hal.

23 Depag RI, al Qur'an dan Terjemahnya, (CV Adi Grafika, 1994) hal. 853

24 Syaiful Sagala, Administrasi... , op.cit., hal. 59

25 Nanang Fattah, op.cit, hal. 101 
dasar melakukan kontrol.

2) Mengukur pelaksanaan pekerjaan dengan standar.

3) Menentukan kesenjangan (deviasi) bila terjadi, antara pelaksanaan dengan standar.

4) Melakukan tindakan-tindakan perbaikan jika terdapat kesenjangan (deviasi) agar pelaksanaan dan tujuan sesuai dengan rencana.

e. Manajemen Kesiswaan

Manajemen kesiswaan (murid) adalah seluruh proses kegiatan yang direncanakan dan diusahakan secara sengaja serta pembinaan secara kontinyu terhadap seluruh peserta didik (dalam lembaga pendidikan yang bersangkutan) agar dapat mengikuti proses belajar mengajar secara efektif dan efisien mulai dari penerimaan peserta didik hingga keluarnya peserta didik dari suatu sekolah. ${ }^{26}$

Manajemen kesiswaan bertujuan untuk mengatur berbagai kegiatan dalam bidang kesiswaan agar kegiatan pembelajaran di sekolah dapat berjalan lancar, tertib, teratur, serta dapat mencapai tujuan pendidikan sekolah. Untuk mewujudkan tujuan sekolah tersebut manajemen kesiswaan meliputi empat kegiatan, yaitu: pertama, penerimaan siswa baru, kedua, kegiatan kemajuan belajar, ketiga, bimbingan dan, keempat, pembinaan disiplin serta monitoring. ${ }^{27}$

1. Penerimaan Siswa Baru

Penerimaan siswa baru merupakan salah satu kegiatan yang pertama dilakukan sehingga harus dikelola sedemikian rupa supaya kegiatan belajar mengajar sudah dapat dimulai pada hari pertama setiap tahun ajaran baru. Langkah-langkah penerimaan siswa baru secara garis besar dapat ditentukan sebagai berikut:

a. Menentukan panitia

b. Menentukan syarat-syarat penerimaan

c. Mengadakan pengumuman, menyiapkan soal-soal tes un-

26 Ary Gunawan, Administrasi Sekolah; Administrasi Pendidikan Mikro, (Jakarta: PT RinekaCipta, 1996), Cet.I., hal. 9.

27 Mulyasa, Op.Cit. hal. 46. tuk seleksi

d. menyiapkan tempatnya

e. Melaksanakan penyaringan melalui tes tertulis maupun lisan

f. Mengadakan pengumuman penerimaan

g. Mendaftar kembali calon siswa yang diterima

h. Melaporkan hasil pekerjaan kepada kepala sekolah. ${ }^{28}$

Pedoman-pedoman atau peraturan yang berhubungan dengan penerimaan siswa baru meliputi masalah teknik pelaksanaan, yang menyangkut masalah waktu, persyaratan dan teknis administrasi antara lain :

1. Masalah Waktu:

1) Kapan pendaftaran calon siswa baru dimulai dan diakhiri

2) Kapan tes/ujian seleksi dilaksanakan

3) Kapan hasil tes diumumkan

2. Masalah Persyaratan:

1) Besarnya uang pendaftaran

2) Berapa rata-rata nilai raport yang bisa diterima sebagai pendaftar

3) STTB/ijazah dan foto copy ijazah terakhir yang sudah di sahkan oleh yang berwenang

4) Pas foto (selain jumlah ditentukan juga ukurannya). ${ }^{29}$

3. Proses Penerimaan Siswa Baru

Proses penerimaan siswa baru yang biasa dilakukan pada dasarnya ada tiga cara, yaitu:

a) Ujian/Tes

Ujian/tes yang diselenggarakan dalam rangka memilih calon-calon siswa yang akan diterima, bisa disebut ujian masuk atau tes masuk (entrance test). Tes masuk ini diselenggarakan oleh sekolah masing-masing, tetapi bisa juga gabungan beberapa sekolah dalam satu wilayah atau daerah. Mata pelajaran yang diujikan, jenis-jenis soal yang digunakan, serta cara-cara mengevaluasi ditentukan oleh sekolah. Sedang penentuan calon

28 Suharsimi Arikunto, Op.Cit., hal. 53.

29Soekarto Hendra Fachrudin dan Hendyat Soetopo, Op.Cit., hal. 94. 
siswa yang diterima didasarkanpada peringkat (ranking) jumlah nilai yang dicapai.

b) Penelusuran Bakat Kemampuan

Yang dimaksud dengan bakat kemampuan disini ialah pembawaan-pembawaan yang menunjukkan adanya potensi-potensi yang cukup bagus. Gambaran tentang adanya potensi yang bagus di tunjukkan (menurut kesepakatan keyakinan kita) oleh prestasi siswa dalam berbagai mata pelajaran atau mata pelajaran tertentu di sekolah. Oleh karena itu dalam penelusuran bakat kemampuan ini dilaksanakan dengan cara meneliti atau menjajaki angka-angka prestasi siswa dalam satu atau dua tahun selama siswa mengikuti pelajaran disekolah. Dari hasil penjajakan ini dipanggil calon-calon siswa yang kiranya berminat atau bersedia menjadi siswa di suatu sekolah.

c) Berdasarkan Hasil EBTA (Ujian Akhir Sekolah)

Akhir-akhir ini dikembangkan sistem penerimaan siswa baru, yang boleh dikatakan sebagai pengganti sistem tes masuk. Sistem ini angka-angka atau nilainilai hasil Ujian Akhir Madrasah (UAM) atauUjian Akhir Nasional (UAN) sebagai dasar kriteria untuk menentukan penerimaan siswa baru. Nilai-nilai UAM/ UAN tersebut diberi nama istilah : DNU (Daftar Nilai Ujian). Kemudian nilai-nilai itu disusun dalam suatu standar, dan berdasarkan peringkat DNU dari para calon siswa yang mendaftar, ditentukan siapa-siapa yang diterima sebagai siswa baru di suatu sekolah. ${ }^{30}$

d) Orientasi Siswa Baru

Setiap anak atau siswa saat memasuki lingkungan baru akan mengalami kesulitan, baik disebabkan oleh situasi maupun karena praktek dan prosedur yang berbeda. Kesulitan itu kalau tidak diatasi dapat menimbulkan ketegangan jiwa. Supaya tidak mengalami ketegangan, administrator pendidikan seyogyanya memberi penjelasan-penjelasan tentang hal-hal yang berkaitan

$30 \mathrm{Ibid}$, hal. 96 dengan sekolah. ${ }^{31}$

Orientasi siswa baru adalah kegiatan yang merupakan salah satu bagian dalam rangka proses penerimaan siswa baru. Istilah yang digunakan adalah Masa Orientasi Siswa Baru (MOS). Tujuan orientasi siswa baru yaitu pengenalan bagi siswa baru mengenai keadaan-keadaan sekolah, antara lain meliputi tata tertib, kondisi siswa serta pengenalan pelajaran yang akan dihadapi, ini dimaksudkan agar siswa nanti tidak akan mengalami kejanggalan dalam menempuh studi. Kegiatan-kegiatan yang harus diikuti oleh siswa baru antara lain adalah :

a) Perkenalan dengan para guru dan staf sekolah

b) Perkenalan dengan siswa lama dan pengurus OSIS

c) Penjelasan tentang tata tertib sekolah

d) Mengenal dan meninjau fasilitas-fasilitas sekolah (misalnya: laboratorium, perpustakaan, ruang pertemuan (AULA), sanggar kesenian dan lain sebagainya. ${ }^{32}$

Waktu MOS juga untuk penelusuran bakat-bakat khusus dan siswa baru, misalnya penelusuran bakatbakat olah raga, bakat-bakat seni, bakat-bakat menulis (mengarang). Oleh karena itu selama MOS banyak diisi kegiatan-kegiatan pertandingan olah raga, lomba menyanyi, pidato, dan sebagainya.

2. Pendataan Kemajuan Belajar Siswa

Keberhasilan kemajuan untuk prestasi belajar para siswa memerlukan data yang otentik, terpercaya dan memiliki keabsahan. Data ini diperlukan untuk mengetahui dan mengontrol keberhasilan atau prestasi oleh kepala sekolah sebagai manajer pendidikan di sekolah. Kemajuan belajar siswa secara periodik harus dilaporkan kepada orang tua sebagai masukan untuk berprestasi dalam proses pendidikan dan membimbing anaknya dalam belajar baik di rumah maupun

31 Drs. Harbangan Siagin, Administarsi Pendidikan suatu Pendekatan Sistemik, (Semarang: PT Satya Wacana, 1989), Cet.I, hal. 100.

32 Drs. Soekarto Hendra Fachrudin, Drs. Hendyat Soetopo, Op.Cit., hal. 98. 
di sekolah..$^{33}$

Dalam pendataan kemajuan belajar siswa untuk kemajuan dan keberhasilan kegiatan belajar mengajar secara maksimal diperlukan buku catatan prestasi belajar murid, yang meliputi buku daftar nilai, buku legger dan raport.

a. Buku Daftar Nilai

Buku ini merupakan buku pertama yang digunakan oleh guru untuk mencatat nilai mentah yang diperoleh langsung dari ulangan harian atau ulangan umum, serta nilai-nilai lain seperti nilai tugas dan aktivitas.

b. Buku Legger

Yaitu buku kumpulan nilai yang memuat semua nilai untuk semua bidang studi yang diikuti oleh siswa didalam periode tertentu. Buku legger ini diisi oleh wali kelas yang menampung nilai-nilai dari guru-guru yang memegang pelajaran di kelas tersebut. Sekolah juga memiliki buku legger yang merupakan kumpulan nilai dari legger-legger kelas.

c. Buku Raport

Merupakan sebuah buku yang memuat laporan hasil belajar yang bersangkutan mengikuti pendidikan di sekolah. Buku raport bukan hanya berguna bagi murid itu sendiri untuk dapat mengetahui prestasinya selama suatu periode, tetapi juga bagi orang tua siswa, tujuannya adalah agar orang tua dapat mengetahui tentang kemajuan belajar atau prestasi putranya di sekolah. ${ }^{34}$

Guru dan pengelola pengajaran mengadakan penilaian dengan tujuan apakah usaha yang dilakukan melalui pengajaran sudah mencapai tujuan yang diharapkan atau belum. Karena dari hasil penilaian yang diperoleh guru akan dapat mengetahui mana siswa-siswinya yang sudah berhak melanjutkan pelajaran atau sudah berhasil menguasai bahan, maupun untuk mengetahui siswasiswinya yang belum menguasainya.

33 Oteng Sutisna, Administrasi Pendidikan; Dasar Teoritis untuk Praktek

Profesional,(Bandung: Angkasa, 1989), hal. 90.

34 Suharsimi Arikunto, Op.Cit., hal. 57.
Dengan petunjuk ini guru akan dapat lebih memusatkan perhatiannya kepada siswa-siswinya yang belum berhasil. Apabila guru mengetahui sebab-sebabnya, guru akan memberikan perhatian yang memusat dan memberikan perlakuan yang lebih teliti sehingga keberhasilan selanjutnya dapat diharapkan. ${ }^{35}$

Tujuan atau fungsi penilaian dari beberapa buku penting di atas, antara lain:

a. Penilaian Berfungsi Selektif

Dengan cara mengadakan Penilaian, guru mempunyai cara untuk mengadakan seleksi atau penilaian terhadap siswanya. Penilaian itu sendiri mempunyai berbagai tujuan antara lain :

1. Untuk memilih atau menentukan siswa yang dapat naik kelas atau tingkat berikutnya.

2. Untuk memilih siswa yang seharusnya mendapat beasiswa.

3. Untuk memilih siswa yang berhak meninggalkan sekolah dan lain sebagainya.

b. Penilaian Bersifat Diagnosis

Apabila alat yang digunakan untuk melakukan penilaian cukup memenuhi persyaratan, maka dengan melihat hasilnya guru akan mengetahui kelemahan siswa. Disamping itu diketahui pula sebab-sebab kelemahan itu. Jadi dengan mengadakan penilaian sebenarnya guru mengadakan diagnosa kepada siswa tentang kebaikan dan kelemahannya. Dengan diketahui sebab-sebab kelemahannya akan lebih mudah dicari cara mengatasinya.

c. Penilaian Berfungsi Sebagai Pengukur Keberhasilan

Fungsi dari penilaian ini dimaksudkan untuk mengetahui sejauhmana suatu program berhasil diterapkan. Keberhasilan program ditentukan oleh beberapa faktor, salah satunya yaitu sistem administrasi. ${ }^{36}$

35 Suharsimi Arikunto, Dasar-Dasar Evaluasi Pendidikan, (Yogyakarta: Bumi Aksara, 1995), hal. 6

36 Ibid, hal. 5 
Untuk mempermudah jalannya peninjauan gerak langkah maju mundurnya proses belajar mengajar pada suatu lembaga pendidikan maka, perlu adanya evaluasi hasil belajar yang dibukukan melalui buku nilai, buku legger dan raport siswa. Karena buku tersebut sangat diperlukan untuk melengkapi proses administrasi di instansi sekolah dalam rangka mencapai tujuan pendidikan. Adapun tujuan dari beberapa buku penting tersebut antara lain:

a) Untuk mengetahui derajat penguasaan materi

b) Untuk dapat menentukan tindakan perbaikan yang akan diambil

c) Untuk menentukan penempatan siswa dalam pengelompokan mata pelajaran

d) Untuk menentukan prestasi siswa. ${ }^{37}$

Untuk memacu prestasi siswa, maka kepada tiaptiap guru diharuskan segera memeriksa, menilai, dan mengembalikan tugas-tugas yang dibebankan kepada siswanya.

3. Bimbingan dan Pembinaan Disiplin Siswa

a. Bimbingan

Bimbingan adalah pelayanan komprehensif yang tidak dapat dilakukan semata-mata satu orang saja, melainkan seluruh personal sekolah perlu menunjang pelaksanaan itu agar tepat berfungsi secara penuh dan efektif. ${ }^{38}$

Secara khusus layanan bimbingan bertujuan untuk membantu siswa agar dapat tercapai tujuan-tujuan perkembangan meliputi aspek pribadi, sosial, belajar dan karir bimbingan pribadi, sosial dalam mewujudkan pribadi yang bertaqwa, mandiri, dan bertanggung jawab.

Bimbingan belajar dimaksudkan untuk mencapai tujuan dan tugas perkembangan pendidikan. Konselor di-

37 Harbangan Siagi, Op.Cit., hal. 105.

38 Dewa Ketut Sukardi, Pengantar Pelaksanaan Program Bimbingan dan Konseling di Sekolah, (Jakarta: Rineka Cipta, 2000), hal. 52. maksudkan untuk mewujudkan pribadi produktif..

Personel pelaksana pelayanan bimbingan adalah segenap unsur yang terkait di dalam program pelayanan bimbingan dengan koordinator dari guru pembimbing konselor sebagai pelaksana.

Secara umum, bimbingan yang diberikan pihak sekolah terhadap siswa berkaitan dengan hal-hal sebagai berikut:

a. Pilihan bidang studi

b. Penyesuaian kepada situasi sekolah

c. Kesukaran belajar

d. Kesukaran yang bertalian dengan keluarga dan lingkungan

e. Gagal dalam bidang studi tertentu

f. Kebutuhan dan kesempatan rekreasi

g. Kurang minat terhadap bidang studi tertentu

h. Kurang harga diri

i. Hambatan-hambatan fisik, mental, emosi dan penyesuaian murid

j. Pilihan pekerjaan dan penyesuaian waktu senggang

k. Pertentangan antara ambisi dan kesanggupan siswa. ${ }^{40}$

1) Prinsip-prinsip Bimbingan

Prinsip-prinsip merupakan paduan hasil kajian teoritik dan telaahan lapangan yang digunakan sebagai pedoman pelaksanaan sesuatu yang dimaksudkan. Dalam pelayanan bimbingan terhadap siswa, prinsipprinsipyang digunakan menurut Van Hoosea dalam Harbangan Siagin adalah sebagai berikut :

a. Bimbingan didasarkan pada keyakinan bahwa dalam diri tiap anak terkandung kebaikan-kebaikan, setiap pribadi mempunyai potensi dan pendidikan hendaklah mampu membantu anak memanfaatkan

39 Hadari Nawawi, Administrai dan Organisasi Bimbingan dan Penyuluhan, (Jakarta: Ghalia Indonesia, 1983), hal. 53.

40 Harbangan Siagin, Op.Cit., hal. 100. 
potensinya itu.

b. Bimbingan merupakan bantuan kepada anak dan pemuda dalam pertumbuhan dan perkembangan mereka menjadi pribadi-pribadi yang sehat.

c. Bimbingan dalam prinsipnya harus menyeluruh ke semua murid karena semua orang tentu mempunyai masalah yang butuh pertolongan. ${ }^{41}$

2) Tujuan Bimbingan di Sekolah

Tujuan bimbingan dan penyuluhan di sekolah tidak lepas dari tujuan pendidikan dan pengajaran pada khususnya dan pendidikan pada umumnya. Yaitu yang tercantum dalam Undang-Undang No. 20 Tahun 2003 dalam Bab II Pasal 3 yang berbunyi "Pendidikan nasional berfungsi mengembangkan kemampuan dan membentuk watak serta peradaban bangsa yang bermartabat dalam rangka mencerdaskan kehidupan bangsa, bertujuan untuk berkembangnya potensi peserta didik agar menjadi manusia yang beriman dan bertaqwa pada TuhanYang Maha Esa, berakhlak mulia, sehat, berilmu, cakap, kreatif, mandiri, dan menjadi warga negara yang demokratis serta bertanggung jawab". ${ }^{42}$

Menurut Djumhur dalam bukunya Bimbingan dan Penyuluhan di Sekolah ada tujuan dan layanan bimbingan di sekolah yang diselenggarakan bagi peserta didik, yaitu:

a. Membantu peserta didik untuk mengembangkan pemahaman diri sesuai dengan kecakapan, minat pribadi, hasil belajar serta kesempatan yang ada

b. Membantu peserta didik untuk mengembangkan motif-motif intrinsik dalam belajar, sehingga tercapai kemajuan pengajaran yang berarti dan bertujuan c. Memberikan dorongan dalam pengarahan diri, pem-

41 Priyatno, Drs. Ermawanti, Dasar-Dasar Bimbingan dan Konseling, (Jakarta: PT Rineka Cipta, 1999), Cet. I, hal. 218

42 Undang-undang RI. No. 20 Tahun 2003, Sistem Pendidikan Nasional dan Penjelasannya, (Bandung: Citra Umbara, 2003), hal. 7 ecahan masalah, pengambilan keputusan dan keterlibatan diri dalam proses pendidikan

d. Mengembangakan nilai dan sikap secara menyeluruh serta perasaan sesuai perencanaan diri

e. Membantu peserta didik untuk memperoleh penyesuaian diri dalam beradaptasi secara maksimal terhadap masyarakat.

f. Membantu peserta didik untuk hidup seimbang dalam berbagai aspek fisik, mental, dan sosial. ${ }^{43}$

Dengan demikian maka tujuan bimbingan dan penyuluhan di sekolah ialah membantu tercapainya tujuan pendidikan dan pengajaran serta membantu individu (siswa) untuk mencapai kesejahteraan.

3) Fungsi-Fungsi Bimbingan

Fungsi bimbingan dan penyuluhan dalam proses pendidikan dan pengajaran ialah membantu tercapainya tujuan pendidikan dan pengajaran. Karena itu segala langkah, bimbingan, dan penyuluhan harus sejalan dengan langkah-langkah yang diambil dari segi pendidikan. Sehingga suatu hal yang wajar dengan adanya bimbingan dan penyuluhan itu diharapkan pendidikan akan berlangsung lebih lancar dan mengefektifkan program sekolah. ${ }^{44}$

Fungsi bimbingan ditinjau dari kegunaan atau manfaat ataupun keuntungan-keuntungan apa yang diperoleh melalui pelayanan tersebut. Fungsi-fungsi itu banyak namun dapat dikelompokkan menjadi empat fungsi pokok, yaitu:

a. Fungsi Pemahaman

Fungsi bimbingan dan konseling yang akan menghasilkan pemahaman tentang sesuatu oleh pihak-pihak tertentu sesuai dengan kepentingan

43 Djumhur dan Moh. Surya, Bimbingan dan Penyuluhan di Sekolah, (Bandung: CV. Ilmu, 1989), hal. 30

44 Bimo Walgito, Bimbingan dan Penyuluhan di Sekolah, (Yogyakarta: Andi Offset, 1986), hal. 25. 
pengembangan peserta didik

b. Fungsi Penyaluran

Fungsi bimbingan dan konseling yang membantu peserta didik untuk memilih jurusan sekolah, jenis sekolah, dan lapangan pekerjaan yang sesuai dengan minat, bakat dan ciri-cirikepribadian lainnya.

c. Fungsi Adaptasi

Fungsi membantu petugas-petugas di sekolah, khususnya guru, untuk mengadaptasikan program pendidikan terhadap minat, kemampuan dan kebutuhan para peserta didik. Dengan menggunakan informasi yang memadai mengenai para peserta didik secara tepat, baik dalam mengelola dan memilih materi pelajaran yang tepat, atau dalam mengadaptasikan bahan pelajaran pada kecepatan dan kemampuan peserta didik.

d. Fungsi Penyesuaian

Fungsi bimbingan untuk membantu peserta didik memperoleh penyesuaian pribadi dan memperoleh kemajuan dalam perkembangannya secara optimal. Fungsi ini dilaksanakan dalam rangka mengidentifikasi, memahami, dan memecahkan masalah. ${ }^{45}$

4) Kegiatan-Kegiatan Bimbingan

Ada beberapa kegiatan dalam bimbingan di sekolah, di antaranya adalah:

a. Bimbingan pendidikan adalah bertujuan untuk membantu seseorang dalam memilih program yang tepat

b. Bimbingan belajar ialah memberikan bantuan kepada individu dalam memecahkan kesulitan yang berhubungan dengan masalah belajar

c. Bantuan dalam kesulitan belajar maksudnya agar siswa dapat memperoleh sukses dalam belajar secara optimal sesuai dengan potensi yang dimilikinya

45 Achmad Juntika Nurihsan, Akur Sudianto, Manajemen Bimbingan dan Konseling di SMP Kurikulum 2004.(Jakarta: PT Grasindo, 2005), hal. 14-15. d. Bantuan dan mekanisme bimbingan dalam pelaksanaannya dapat berjalan secara teratur dan mencapai tujuan diperlukan adanya administrasi yang baik serta perlengkapannya

e. Fasilitas dan anggaran merupakan penunjang bagi terlaksananya program bimbingan di sekolah, seperti ruangan yang memberikan kesan yang nyaman, menyenangkan untuk pelaksanaan bimbingan. ${ }^{46}$

b. Pembinaan Disiplin Siswa

Allah selalu memberikan contoh untuk berlaku disiplin sesuai dengan aturan. Sebagai contoh Allah menciptakan alam seisinya ini semua ditata sedemikian rupa, jika salah satu diantara yang ada tidak memenuhi aturan yang ada, maka kelangsungan alam ini terancam. Dalam surat Yasin ayat $38-40$ disebutkan :

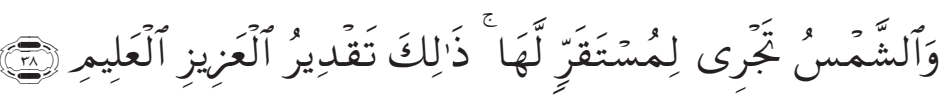

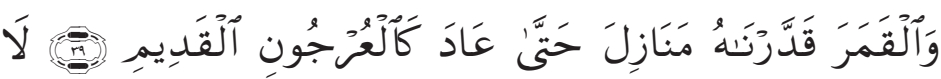

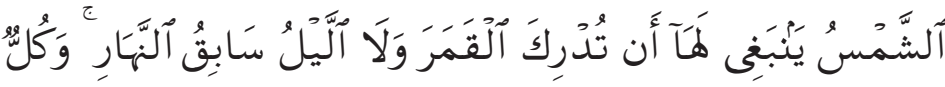

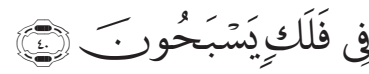

Artinya: (38) dan matahari berjalan ditempat peredarannya. Demikianlah ketetapan yang Maha Perkasa lagi Maha mengetahui. (39) dan telah Kami tetapkan bagi bulan manzilahmanzilah, sehingga (setelah Dia sampai ke manzilah yang terakhir) Kembalilah Dia sebagai bentuk tandan yang tua[1267]. (40) tidaklah mungkin bagi matahari mendapatkan bulan dan malampun tidak dapat mendahului siang. dan masing-masing beredar pada garis edarnya.

[1267] Maksudnya: bulan-bulan itu pada Awal bulan, kecil berbentuk sabit, kemudian sesudah menempati manzilah-

\footnotetext{
46 Hendrat Soetopo dan Wasty Sumanto, Pengantar Operasional Administrasi
} Pendidikan, (Surabaya: Usaha Nasional, 1982), hal. 134. 
manzilah, Dia menjadi purnama, kemudian pada manzilah terakhir kelihatan seperti tandan kering yang melengkung.

Demikian halnya penciptaan tatanan kehidupan manusia sehari-hari diperlukan suatu tatanan atau aturan sebagai pedoman agar tercapai suatu kehidupan yang teratur, rapi, harmonis, dan serasi.

Disiplin sekolah ialah keadaan tertib dimana para guru, staf sekolah dan siswa yang tergabung dalam sekolah, tunduk kepada peraturan-peraturan yang telah ditetapkan dengan senang hati. ${ }^{47}$ Disiplin siswa dimaksudkan untuk mengarahkan siswa agar tumbuh dan berkembang sesuai kapasitas dan kemampuan bakat dan minat serta menjadi pribadi yang utuh sebagai makhluk individu dan sosial, cerdas, terampil dan bermoral. ${ }^{48}$

Menurut asal-usul kata (etimologi), kata disiplin berasal dari bahasa Latin yakni discilpina dan merupakan bentuk kata dari discipulus yang berarti seseorang yang datang kepada orang lain dengan tujuan belajar, yaitu siswa (Oxford:). Sehingga dengan disiplin diperoleh sesuatu yang terkait dengan pengetahuan, sikap dan perilaku yang sesuai dengan aturan. Sedang dalam bahasa Inggris digunakan istilah discipline yang berarti (a method of) training to produce obedience end self control yang dalam bahasa Indonesia diterjemahkan "suatu metode/cara latihan mengembangkan ketaatan dan kendali diri. Dan selanjutnya dijelaskan bahwa self discipline (kendali diri) diartikan dengan the training of one self to controlone's habits, actions, and desires (latihan seseorang untuk mengontrol kebiasaan, kegiatan dan nafsunya). ${ }^{49}$

Jadi kedisplinan siswa adalah sikap seorang murid yang patuh atau tunduk terhadap peraturan yang ada di lingkungan (sekolah).

47 Soekarto Indra Fachrudin dan Hidayat Soetopo, Op.Cit., hal.108.

48 Puslitbang Pendidikan Agama dan Keagamaan Badan Litbang Agama dan Diklat Keagamaan, 2003, Cet. III, hal. 77.

49 Nurul Huda, Bahan Penataran MOS: Disiplin dalam kehidupan sehari-hari, (Semarang: Ma'arif, 2003), hal. 24-25.
1. Tujuan Disiplin

Dalam dunia pendidikan, sangat diperlukan adanya disiplin sebagai alat yang mengikat dalam dunia pendidikan, dengan kedisiplinan anak dapat diarahkan, dibimbing dan dididik, sehingga tujuan pendidikan dapat tercapai secara optimal. Kebutuhan akan kedisiplinan sangat diperlukan dalam dunia pendidikan, berikut ini terdapat beberapa tujuan dari kedisiplinan.

a. Menurut Charles Schaefer tujuan adanya disiplin dibedakan jadi dua macam yaitu : disiplin jangka panjang dan disiplin jangka pendek. Tujuan jangka pendek dari disiplin adalah membuat anak-anak terlatih dan terkontrol, dengan mengajarkan pada mereka bentuk-bentuk tingkah laku yang pantas atau masih asing bagi mereka. Sedang tujuan jangka panjang yaitu untuk pengembangan pengendalian diri sendiri dan pengarahan diri sendiri yaitu agar anak dapat mengarahkan diri sendiri tanpa pengaruh dan pengendalian dari luar. ${ }^{50}$

b. Eg. White mengatakan tujuan dari disiplin adalah mendidik seorang anak. Untuk memelihara diri, ia harus berstandar dalam mengendalikan diri. ${ }^{51}$

Berpijak dari berbagai tujuan yang dikemukakan di atas pada dasarnya tujuan kedisiplinan siswa adalah agar siswa terlatih dalam mengendalikan dan mengarahkan dirinya dalam lingkungan keberadaannya, sehingga timbul rasa tanggung jawab dan kematangan dari dirinya sendiri demi kebahagiaan untuk hidup masa depan.

2. Fungsi-fungsi Disiplin

a. Membangun Kepribadian.

Kepribadian adalah keseluruhan sifat, tingkah

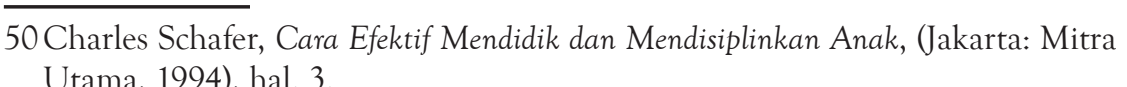

51 Eg. White, Mendidik dan Membimbing Anak, (Bandung: Publishing House, 1994), hal. 213 
laku dan pola hidup seseorang yang tercermin dalam penampilan, perkataan, dan perbuatan sehari-hari, sifat, tingkah laku dan pola hidup pertumbuhan kepribadian seseorang biasanya dipengaruhi oleh faktor lingkungan, keluarga, pergaulan, dan sekolah.

Disiplin yang diterapkan di masing-masing lingkungan tersebut memberi dampak bagi pertumbuhan kepribadian yang baik. Oleh karena itu, dengan disiplin, seorang anak dibiasakan mengikuti, mematuhi, dan mentaati aturan-aturan yang berlaku. Kebiasaan itu, lama-kelamaan masuk ke dalam kesadaran dirinya sendiri sehingga akhirnya menjadi kepribadiannya. Disiplin telah menjadi bagian dalam kehidupan sehari-hari.

Menurut Singgih D. Gunarso dalam Tulus Tu'u mengatakan bahwa fungsi disiplin adalah untuk mengajarkan mengendalikan diri dengan mudah, menghormati, dan mematuhi otoritas. ${ }^{52}$

b. Terciptanya Lingkungan Kondusif.

Sekolah sebagai ruang lingkungan pendidikan perlu menjamin terselenggaranya proses pendidikan yang baik. Kondisi yang baik bagi proses tersebut adalah kondisi aman, tentram, tertib dan teratur, saling menghargai, dan hubungan pergaulan yang baik. Apabila kondisi ini terwujud sekolah akan menjadi lingkungan kondusif bagi kegiatan dan proses pendidikan. Sebab unsur yang menghambat proses pendidikan dapat diatasi dan diminimalkan oleh situasi kondusif tersebut.

c. Melatih Kepribadian.

Kepribadian yang tertib, teratur, dan patuh perlu dibiasakan dan dilatih. Pola hidup seperti itu mustahil dapat terbentuk begitu saja. Hal ini membutuhkan waktu dan proses yang butuh waktu lama, perlu adanya latihan, pembiasaan diri, mencoba, dan berusaha dengan gigih.

d. Menata Kehidupan Bersama.

Dalam hubungan bersama diperlukan norma, nilai peraturan untuk mengatur agar kehidupan dan kegiatan dapat berjalan dengan baik dan lancar. Kepentingan individu yang satu tidak berbenturan dengan kepentingan individu yang lain.

Jadi fungsi disiplin adalah mengatur tata kehidupan manusia dalam kelompok tertentu atau dalam masyarakat dengan begitu hubungan individu satu dengan yang lain menjadi baik dan lancar. ${ }^{53}$

Kegiatan pembinaan disiplin siswa dapat dilaksanakan melalui kegiatan organisasi kesiswaan (OSIS), kegiatan kokurikuler, dan ekstrakurikuler. a. Kegiatan Organisasi Siswa (OSIS)

OSIS merupakan organisasi murid yang resmi diakui dan diselenggarakan di sekolah dengan tujuan melatih kepemimpinan murid serta memberi wahana bagi murid untuk melakukan kegiatan-kegiatan ko-kurikuler yang sesuai, oleh karena itu supaya pembinaan administrasinya terutama menyangkut pembinaan pengelolaan organisasi dan kegiatannya, apapun kegiatannya yang dikembangkan hendaknya selalu dalam rangkaian dan tujuannya, yaitu pengembangan pengetahuan dan kemampuan penalaran, pengembangan keterampilan dan pengembangan sikap, selaras dengan tujuan sekolah yang tertuang dalam kurikulum. ${ }^{54}$

OSIS merupakan satu-satunya wadah untuk menampung dan menyalurkan kreativitas siswa baik melalui kegiatan ko-kurikuler maupun ekstrakurikuler dalam menunjang tercapainya

53 Ibid, hal. 38

54 M. Daryanto, Administrasi Pendidikan, (Jakarta: PT Asdi Maha Satya, 2001), hal. 62. 
keberhasilan kegiatan kurikuler di sekolah. ${ }^{55}$

Adapun fungsi OSIS ialah pembinaan siswa. Pembinaan siswa mempunyai tujuan, agar siswa nantinya bisa menjadi warga negara yang baik dan berguna, yaitu sesuai dengan tujuan pendidikan nasional dan bertakwa kepada $\mathrm{Tu}$ han Yang Maha Esa, cerdas dan terampil, berbudi pekerti luhur, berkepribadian dan bersemangat kebangsaan, menjadi manusia-manusia pembangunan, yang mampu membangun dirinya sendiri dan bersama-sama bertanggung jawab atas pembangunan bangsa. ${ }^{56}$

Nilai-nilai dari OSIS adalah nilai berorganisasi. Pengalaman-pengalaman berorganisasi ini diantaranya adalah:

1) Pengalaman memimpin

Khususnya ini bagi anggota pengurus, yang duduk sebagai ketua organisasi maupun ketua-ketua seksi.

2) Pengalaman bekerja sama

Seluruh pengurus dan juga anggota, untuk melaksanakan program-programnya harus saling bekerja sama.

3) Hidup demokratis

Dalam organisasi tidak bisa seseorang memaksakan kehendaknya begitu saja kepada orang lain anggota organisasi tersebut. Semua anggota mempunyai hak dan kedudukan yang sama.

4) Berjiwa toleransi

Anggota dari suatu organisasi bisa mempunyai pendapat dan pandangan yang berbedabeda. Setiap anggota harus rela menerima keberadaan itu, dan berusaha memadukannya

55 Depdikbud, Pedoman Umum Penyelenggararaan Administrasi Sekolah Menengah, (Jakarta: Balai Pustaka, 1989), Cet.I, hal. 351

56 Soekarto Indra Fachrudindan dan Hidayat Soetopo, Op. Cit., hal. 148 menjadi suatu yang berguna.

5) Pengalaman mengendalikan diri

Pengalaman ini meliputi pengalaman bagaimana merencanakan program-program kegiatan, bagaimana mengorganisasi kegiatan-kegiatan, bagaimana menggerakkan dan mengarahkan orang-orang, menilai dan mengukur keberhasilan dari suatu kegiatan. ${ }^{57}$

b. Kegiatan Ko-Kurikuler

Namun kegiatan ko-kurikuler masih tetap berhubungan dengan mata pelajaran sekolah seperti drama, tilawatil Qur'an, kegiatan ilmiah remaja, ini untuk menambah pengetahuan siswa, dan kegiatan olah raga yang dipelajari di sekolah. Tujuan kegiatan ko-kurikuler adalah sebagai berikut:

1) Pengembangan kepemimpinan

2) Perbaikan moral siswa

3) Praktek proses demokrasi

4) Pembangunan sosial dan agama

5) Meningkatkan rasa tanggung jawab diantara siswa

6) Pelestarian tradisi budaya, agama, masyarakat, dan sekolah. ${ }^{58}$

Beberapa kegiatan ko-kurikuler yang ada di madrasah antara lain :

1) Pengembangan atletik dan fisik

2) Pidato dan drama

3) Jurnalistik

4) Tilawatil Qur'an

5) Rekreasi

6) Hobbi

7) Pembangunan sosial

8) Klub

57 Ibid, hal. 127.

58 Ghulam Farid Malik, Pedoman Manajemen Madrasah, (Yogyakarta: FkBA, 2000), hal. $77-78$ 
9) Pramuka, dan lain-lain.59

c. Kegiatan Ekstra Kurikuler

Yang dimaksud ekstra kurikuler di sini adalah kegiatan pendidikan yang dilaksanakan sekolah, namun pelaksanaanya diluar jam-jam pelajaran resmi. Artinya di luar jam-jam pelajaran yang tercantum dalam jadwal pelajaran. ${ }^{60}$

Kegiatan ekstrakurikuler merupakan kegiatan yang dilakukan di luar kelas dan di luar jam pelajaran (kurikulum) untuk menumbuh kembangkan potensi sumber daya manusia (SDM) yang dimiliki peserta didik (siswa) baik berkaitan dengan aplikasi ilmu pengetahuan yang didapatkannya maupun dalam pengertian khusus untuk membimbing siswa dalam mengembangkan potensi dan bakat yang ada dalam dirinya melalui kegiatan-kegiatan yang wajib maupun pilihan. ${ }^{6}$

\section{Monitoring}

Monitoring adalah suatu proses pemantauan untuk mendapatkan informasi tentang pelaksanaan suatu kegiatan yakni manajemen kesiswaan. Kegiatan monitoring adalah suatu kegiatan memonitor atau mengawasi seluruh aktivitas yang dilakukan oleh seluruh warga sekolah, dalam hal ini difokuskan pada aktivitas-aktivitas yang dilakukan oleh siswa. ${ }^{62} \mathrm{Ke}$ giatan monitoring ini dapat dilakukan secara langsung pada kegiatan yang sedang dilakukan oleh siswa dan kegiatan monitoring secara tidak langsung dengan mendengarkan laporan dari orang yang terlibat dalam kegiatan.

Jadi fokus monitoring adalah proses pelaksanaan manajemen kesiswaan, bukan pada hasil. Sehingga tujuan monitoring adalah untuk mendapatkan informasi yang dapat digunakan

\section{$59 \mathrm{Ibid}$, hal. 73}

$60 \mathrm{Ibid}$, hal. 122

61 Departemen Agama RI, Kegiatan Ekstrakurikuler Pendidikan Agama Islam Pada

Sekolah Umum dan Madrasah, (Jakarta:Depag, 2004), hal.10

62 Puslitbang, Op.Cit., hal. 93 untuk pengambilan keputusan. Apa yang harus dilakukan dan bagaimana langkah melakukannya dengan dasar hasil monitoring tersebut.

\section{Penutup}

Manajemen Peserta didik atau Pupil Personnel Administration adalah layanan yang memusatkan perhatian pada pengaturan dan pengawasan siswa di kelas dan luar kelas. Seperti : pengenalan, pendaftaran, layanan individual seperti penggembangan keseluruhan kemampuan, minat, kebutuhan sampai ia matang di sekolah.Tujuan Manajemen Peserta Didik adalah mengatur kegiatan-kegiatan peserta didik agar kegiatan-kegiatan tersebut menunjang proses pembelajaran di lembaga pendidikan (sekolah). Lebih lanjut, proses pembelajaran di lembaga tersebut (sekolah) dapat berjalan lancar, tertib, dan teratur sehingga dapat memberikan kontribusi bagi pencapaian tujuan sekolah dan tujuan pendidikan secara keseluruhan.

Sedangkan fungsinya adalah sebagai wahana bagi peserta didik untuk mengembangakan diri seoptimal mungkin, baik yang berkenaan dengan segi-segi individualitasnya, segi sosial, aspirasi, kebutuhan, dan segi-segi potensi peserta didik lainnya.

Adapun prinsip-prinsip Manajemen Peserta Didik antara lain adalah penyelenggara harus mengacu pada peraturan yang berlaku pada saat program dilaksanakan. Manajemen Peserta Didik harus mempunyai tujuan yang sama dan atau mendukung terhadap tujuan. Segala bentuk kegiatan haruslah mengemban misi pendidikan dan dalam rangka mendidik peserta didik, diupayakan untuk mempersatukan peserta yang mempunyai keragaman latar belakang dan punya banyak perbedaan, sebagai upaya pengaturan terhadap pembimbingan peserta didik, mendorong dan memacu kemandirian peserta didik, fungsional bagi kehidupan peserta didik, baik di sekolah lebih-lebih di masa depan. 


\section{Daftar Pustaka}

Achmad Juntika Nurihsan, Akur Sudianto, Manajemen Bimbingan dan Konseling di SMP Kurikulum 2004. (Jakarta: PT Grasindo, 2005)

Ahmad Rohani dan Abu Ahmadi, Pedoman Penyelenggaraan Administrasi Pendidikan Sekolah, (Jakarta: bumi Aksara, 1991), cet.I

Ary Gunawan, Administrasi Sekolah; Administrasi Pendidikan Mikro, (Jakarta: PT RinekaCipta, 1996), Cet.I.

Bimo Walgito, Bimbingan dan Penyuluhan di Sekolah, (Yogyakarta: Andi Offset, 1986)

Charles Schafer, Cara Efektif Mendidik dan Mendisiplinkan Anak, (Jakarta: Mitra Utama,1994)

Dann Suganha, Kepemimpinan di Dalam Administrasi, (Bandung: Sinar Baru, 1986)

Depag RI, Al Qur'an dan Terjemahnya, (CV Adi Grafika, 1994)

Departemen Agama RI, Kegiatan Ekstrakurikuler Pendidikan Agama Islam Pada SekolahUmum dan Madrasah, (Jakarta:Depag, 2004)

Depdikbud, Pedoman Umum Penyelenggararaan Administrasi Sekolah Menengah, (Jakarta: Balai Pustaka, 1989), Cet.I

Dewa Ketut Sukardi, Pengantar Pelaksanaan Program Bimbingan dan Konseling di Sekolah, (Jakarta: Rineka Cipta, 2000)

Djumhur dan Moh. Surya, Bimbingan dan Penyuluhan di Sekolah, (Bandung: CV. Ilmu,1989)

E. Mulyasa, Manajemen Berbasis Sekolah, (Bandung: PT. Remaja Rosda Karya, 2003), cet. III dan IV

Eg. White, Mendidik dan Membimbing Anak, (Bandung: Publishing House, 1994)

Ghulam Farid Malik, Pedoman Manajemen Madrasah, (Yogyakarta: FkBA, 2000)

Hadari Nawawi, Administrai dan Organisasi Bimbingan dan Penyuluhan, (Jakarta: GhaliaIndonesia, 1983)

Harbangan Siagin, Administarsi Pendidikan suatu Pendekatan Sistemik, (Semarang:PT Satya Wacana, 1989), Cet.I,

Hendrat Soetopo dan Wasty Sumanto, Pengantar Operasional Admin- istrasi Pendidikan, (Surabaya: Usaha Nasional, 1982)

Ibrahim Ishmat Mutthowi, Al-Ushul Al-Idariyah li al-Tarbiyah, (Riyad: Dar al-Syuruq, 1996)

Imam Abi Zakariya bin Syaraf An Nawawi ad Dimsyaqi, Riyadhus Sholihin, (Beirut: Resalah Publisher, 2000)

Iwa Sukiswa, Dasar-Dasar Umum Manajemen Pendidikan, (Bandung: Tarsito, 1986)

John Adair, Effective Leadership; A Self-Development Manual, Penerjemah Andre Asparyasogi, Menjadi Pemimpin Efektif, (Jakarta: PT Gramedia, 1994), cet. IV

John M. Echol dan Hasan Shadily, Kamus Inggris Indonesia, (Jakarta : PT Gramedia, 1996), cet. XXIII

J. Riberu, Dasar-Dasar Kepemimpinan, (Jakarta: Pedoman Ilmu Jaya, 1992)

Kadarmansi dan Jusuf Udaya, Pengantar Ilmu Manajemen, (Jakarta: PT Gramedia PustakaUtama, 1992)

Manullang, Dasar-Dasar Manajemen, (Jakarta: Ghalia Indonesia, 1983), cet. X

Marasudin Siregar, Pengelolaan PEngajaran; suatu Dinamika Profesi Keguruan, dalam Chabib Thoha (eds), PBM-PAI di Sekolah; Eksistensi Proses Belajar Mengajar Pendidikan Agama Islam, (Yogyakarta: Pustaka Pelajar, 1998), cet. I

M. Daryanto, Administrasi Pendidikan, (Jakarta: PT Asdi Maha Satya, 2001)

Nanang Fattah, Landasan Manajemen Pendidikan, (Bandung: Remaja Rosda Karya, 2000)

Nanih Machendrawaty, Agus Ahmad Safei, Pengembangan Masyarakat Islam dari Ideologi, Strategi sampai Tradisi, (Bandung: PT Remaja Rosdakarya, 2001)

Ngalim Purwanto, Administrasi dan Supervisi Pendidikan, (Bandung: PT. Remaja Rosda Karya, 1995), cet. VII

Nurul Huda, Bahan Penataran MOS: Disiplin dalam kehidupan seharihari, (Semarang:Ma'arif,2003)

Oteng Sutisna, Administrasi Pendidikan; Dasar Teoritis untuk Praktek Profesional, (Bandung: Angkasa, 1989)

Peter P. Schoderbek, et.al., Management, (Florida: Harcourt Brace Jovanovich Inc., 1988) 
Puslitbang Pendidikan Agama dan Keagamaan Badan Litbang Agama dan Diklat Keagamaan, 2003, Cet. III

Priyatno, Drs. Ermawanti, Dasar-dasar Bimbingan dan Konseling, (Jakarta: PT RinekaCipta, 1999), Cet. I

Soebagio Atmodiwirio, Manajemen Pendidikan di Indonesia, (Jakarta: Ardadizya Jaya, 2000)

Syaiful Sagala, Konsep dan Makna Pemeblajaran; untuk Membantu MemecahkanProblematika Belajar dan Mengajar, (Bandung: CV. Alfabet, 2004)

Syaiful Sagala, Administrasi Pendidikan Kontemporer, (Bandung: CV. Alfabet, 2000)

Suharsimi Arikunto, Dasar-dasar Evaluasi Pendidikan, (Yogyakarta: Bumi Aksara, 1995)

Tulus Tu'u, Peran Disiplin terhadap Perilaku dan Prestasi Siswa, (Jakarta: Grasindo, 2004)

Undang-undang RI. No. 20 Tahun 2003, Sistem Pendidikan Nasional dan Penjelasannya, (Bandung: Citra Umbara, 2003)

\section{Konsep-Konsep Dasar Pendidikan Islam Terpadu}

Ridhoul Wahidi, M.A.

Kaprodi ilmu al-Qur'an \& Tafsir Fakultas Ilmu Agama Islam (FIAI) Universtas Islam Indragiri (UNISI) Tembilahan Riau

\section{Abstark}

Pendidikan Islam terpadu merupakan tipe atau model pendidikan yang utuh menyeluruh (syumul), integral, bukan parsial. Konsep-konsep Pendidikan Islam terpadu dibagi menjadi dua aspek besar. Aspek internal meliputi bidang aqidah dan pendidikan hati. Aspek berikutnya adalah eksternal yang meliputi akhlak, jasmani dan rohani, sosial, intelektual, dan seks. Konsep-konsep tersebut menjadi dasar pendidikan Islam terpadu yang kemudian dapat dikembangkan dan dipadukan demi terwujudnya pendidikan yang integral sesuai dengan petunjuk al-Qur'an dan Sunnah Rasul dan tercapainya baldatun

$$
\text { tayyibatun ghofur. }
$$

Key Words: Konsep Dasar, Pendidikan Islam, Terpadu

\section{A. Pendahuluan}

Allah menciptakan manusia sebagai makhluk yang memiliki dua dimensi yaitu dimensi ruhani dan material. Manusia pada sisi materi dituntut agar dapat mempertahankan keberlangsungan hidup di dunia. Pada sisi lain, ia juga dituntut mempertahankan sisi ruhaninya, agar ada keseimbangan, tidak berlebihan pada sisi materi atau sisi ruhaninya. ${ }^{1}$

Untuk menyeimbangkan dua dimensi di atas manusia berusaha untuk melakukan segala hal yang dianggap penting demi menjaga dua dimensi tersebut agar tidak berubah dari fungsinya. Salah satu caranya adalah melalui pendidikan Islam, ${ }^{2}$ yang mana pendidikan ini dapat membantu manusia mengembangkan potensi-potensi yang

1 Kholil al Masawi. Bagaimana Membangun Kepribadian Islam Sejati. (Jakarta : lentera. 2002), hlm. 65

2 Pendidikan Islam diartikan sebagai proses membimbing dan mengarahakan pertumbuhan dan perkerbangan anak didik agar menjadi manusia dewasa sesuai tujuan pendidikan Islam;menanamkan takwa dan akhlak serta menegakkan kebenaran dalam rangka membentak manusia yang berkepribadian dan berbudi luhur menurut ajaran islam. Baca lebih lanjut, M, Arifin. Ilmu Pendidikan Islam;Tinjauan Teoritis dan Praktis Berdasarkan Pendekatan Interdisipliner. (Jakarta: Bumi Aksara. 2003), hlm. 29 